\title{
PERANAN NOTARIS DALAM MEMBUAT AKTA AKAD PEMBIAYAAN MURABAHAH DI BMT SYARIAH WANITA ISLAM
}

\author{
Tyas Susilo Haryono, Fifiana Wisnaeni, Irma Cahyaningtyas \\ Program Studi Magister Kenotariatan, \\ Fakultas Hukum, Universitas Diponegoro \\ E-mail : Tyaslanank35@gmail.com
}

\begin{abstract}
Notary Public is a public official appointed by the Government who is authorized to make an authentic deed. Sharia contracts made notarially so that they can be called authentic deeds must comply with the provisions of the applicable laws and regulations, therefore the notary in formulating the form of sharia contract must pay attention to the provisions of the Notary Position Act and the sharia principles contained in the contract. One form of sharia contract that is widely used in BMT cooperatives is murabaha contract. The purpose of writing this article is to find out and analyze the murabahah contract and the role of the notary in making the murabahah financing deed in the BMT Cooperative. The method used in this article is empirical juridical method, descriptive specifications with primary and secondary data and analyzed qualitatively. This article produces: (1) Murabahah Financing Agreement is an agreement in accordance with sharia principles regarding the sale and purchase of goods with an exchange instrument accompanied by specified additions and (2) Notary is a public official who has the authority to make an authentic deed, see the authority and role of the Notary public. very important mentioned above, the Notary must have extensive knowledge or insight, one of them is about the technique of making a deed that will be made later. It is important for a Notary to understand the principles of sharia, the principles whose activities are based on Islamic law.
\end{abstract}

\section{Keywords : murabahah financing agreement; notary public}

\begin{abstract}
Abstrak
Notaris adalah pejabat umum yang diangkat oleh Pemerintah yang berwenang untuk membuat akta otentik. Akad syariah yang dibuat secara notariil agar dapat disebut sebagai akta otentik harus memenuhi ketentuan peraturan perundang-undangan yang berlaku, maka dari itu notaris dalam memformulasikan bentuk akta akad syariah wajib memperhatikan ketentuan Undang-undang Jabatan Notaris dan prinsip-prinsip syariah yang terkandung dalam akad. Salah satu bentuk akad syariah yang banyak digunakan pada koperasi BMT yaitu akad murabahah. Tujuan dari penulisan artikel ini adalah untuk mengetahui dan menganalisis akad murabahah dan peranan Notaris dalam membuat akta akad pembiayaan murabahah di Koperasi BMT. Metode yang digunakan dalam artikel ini adalah metode yuridis empiris, spesifikasi deskriptif dengan data primer dan sekunder serta dianalisis secara kualitatif. Artikel ini menghasilkan: (1) akad Pembiayaan Murabahah adalah perikatan yang sesuai dengan prinsip syariah mengenai jual beli barang dengan alat tukar disertai tambahan yang telah ditentukan dan (2) Notaris merupakan pejabat umum yang memiliki kewenangan membuat akta otentik, melihat kewenangan dan peranan Notaris yang sangat penting tersebut di atas maka Notaris harus memiliki pengetahuan atau wawasan yang luas, salah satunya mengenai teknik pembuatan akta yang akan dibuat nantinya. Penting bagi seorang Notaris untuk memahami prinsip syariah, yaitu prinsip-prinsip yang seluruh aktivitasnya bersumber pada hukum Islam.
\end{abstract}

\section{Kata kunci : akad pembiayaan murabahah; notaris}




\section{A. Pendahuluan}

Notaris adalah pejabat umum yang diangkat oleh Pemerintah yang berwenang untuk membuat akta-akta otentik dan kewenangan lainnya sebagaimana dimaksud dalam Undangundang Jabatan Notaris.(Undang-undang Tentang Jabatan Notaris, 2014). Sehingga Notaris memiliki peranan yang sangat penting dalam usaha menciptakan kepastian hukum dan perlindungan hukum bagi masyarakat. Kepastian dan perlindungan hukum itu terwujud dalam sebuah akta otentik yang dibuat oleh Notaris sebagai alat bukti yang sempurna di Pengadilan. Dikatakan sebagai alat bukti yang sempurna karena akta otentik mengandung tiga kekuatan pembuktian, yaitu pembuktian formal (formele bewijskracht), kekuatan pembuktian lahiriah (uitwendige bewijsracht) dan kekuatan pembuktian material (materiele bewijskracht) (Adjie, Habib \& Hafidh, 2011).

Jasa Notaris sebagai pejabat umum yang memiliki wewenang dalam membuat akta otentik sangat dibutuhkan di dalam lembaga keuangan baik itu Bank maupun Lembaga Keuangan Bukan Bank, salah satunya dalam pembuatan perjanjian (akad) kredit atau pembiayaan sebagai dasar hubungan hukum antara lembaga keuangan dengan masyarakat yang menggunakan jasa lembaga keuangan.

Dalam kategori Bank Indonesia, Lembaga Keuangan Masyarakat (LKM), dibagi menjadi dua yaitu LKM bank dan non bank. LKM yang berwujud bank antara lain BRI Unit Desa, BPR dan Badan Kredit Desa (BKD). Sementara yang berwujud non bank antara lain Koperasi Simpan Pinjam (KSP), Lembaga Dana Kredit Pedesaan, Baitul Maal Wat Tamwil (BMT), Lembaga Swadaya Masyarakat (LSM), Arisan, Pola Pembiayaan Grameen, pola pembiayaan ASA, Kelompok Swadaya Masyarakat (KSM), credit union dan lain-lain (Imaniyati, 2018).

BMT yang berbadan hukum koperasi tunduk pada Undang-undang Nomor 25 tahun 1992 tentang Perkoperasian dan Peraturan Pemerintah Nomor 9 tahun 1995 tentang Pelaksanaan Usaha Simpan Pinjam oleh Koperasi.(Peraturan Pemerintah Tentang Pelaksanaan Kegiatan Usaha dan Simpan Pinjam dan Pembiayaan Syariah Oleh Koperasi., 2017) Dalam menjalankan kegiatan usahanya BMT berpedoman pada Peraturan Pemerintah Nomor 11/PER/M.KUKM/XII/2017 tentang Pelaksanaan Kegiatan Usaha dan Simpan Pinjam dan Pembiayaan Syariah Oleh Koperasi.(Peraturan Pemerintah Tentang Pelaksanaan Kegiatan Usaha dan Simpan Pinjam dan Pembiayaan Syariah Oleh Koperasi., 2017). 
Koperasi sendiri merupakan bentuk badan usaha yang relatif lebih dekat untuk BMT, meskipun sebenarnya tidak terlalu sesuai karena simpan pinjam dalam koperasi khusus diperuntukkan bagi anggota koperasi saja, sebagaimana ternyata dalam pasal 44 ayat Undang-undang No. 25 Tahun 1992 Tentang Perkoperasian mengatur bahwa koperasi dapat menghimpun dana dan menyalurkannya melalui kegiatan usaha simpan pinjam dari dan untuk anggota koperasi yang bersangkutan, atau koperasi lain dan/atau anggotanya (Undang-undang Tentang Perkoperasian, 1992).

Baitul Maal wat Tamwil lebih dikenalnya dengan sebutan BMT. Yang terdiri dari dua istilah yakni baitul maal dan baitul tamwil. Secara harfiah atau lughowi baitul maal berarti rumah dana dan baitul tamwil berarti rumah usaha. Bait yang artinya rumah dan tamwil (pengembangan harta kekayaan) yang asal katanya maalatau harta. Jadi baitul tamwil di maknai sebagai tempat untuk mengembangkan usaha atau tempat mengembangkan harta kekayaan (Rusby, 2016).

Berdasarkan definisi di atas BMT memiliki 2 fungsi, yaitu sebagai baitul maal dan baitul tamwil. Sebagai baitul maal, BMT menerima titipan dana zakat, infak dan sedekah serta mengoptimalkan distribusinya sesuai peraturan dan amanahnya. Sedangkan sebagai baitul tamwil, BMT melakukan kegiatan pengembangan usaha-usaha produktif dan investasi dalam meningkatkan kualitas ekonomi pengusaha mikro dan kecil dengan kegiatan menabung dan menunjang pembiayaan (Prastiawati, Fitriani \& Darma, 2016).

Pada fungsinya sebagai baitul tamwil dapat dipahami bahwa selain berfungsi sebagai lembaga keuangan, BMT juga berfungsi sebagai lembaga ekonomi dan bertugas menghimpun dana dari Anggotanya yang mempercayakan dananya disimpan di BMT dan menyalurkanya dana kepada Anggota yang membutuhkan dalam bentuk pembiayaan. Dalam melaksanakan fungsi menghimpun dana dari Anggota dan masyarakat, BMT menyediakan produk simpanan dalam bentuk tabungan harian, simpanan berjangka, tabungan umroh, tabungan qurban dan bentuk simpanan lainnya yang diperbolehkan oleh Undang-Undang.

Dana yang telah terhimpun tersebut kemudian disalurkan kembali kepada Anggota yang membutuhkan dalam bentuk pembiayaan berprinsip syariah.Dalam fungsi bisnis, BMT merupakan Lembaga Keuangan Bukan Bank (LKBB) yang berlandaskan syariah secara operasionalnya. Dengan pembiayaan model bagi hasil (mudharabah), sistem kemitraan penyertaan modal (musyarakah), dan sistem jual beli dengan margin(murabahah) (Hidayat, 2018). 
Melihat kegiatan BMT dalam menyalurkan dana kepada anggotanya dalam bentuk pembiayaan maka, antara BMT dengan Anggota sangat berkepentingan untuk membuat suatu akad pembiayaan diantara mereka sebagai suatu alat bukti yang akan digunakan sebagai pembuktian yang dibuat oleh atau di hadapan Notaris.

Maka dari itu Notaris yang memformulasikan akad pembiayaan diharapkan memperhatikan rukun dan syarat sahnya akad sebagaimana ditentukan syariat Islam, klausula yang tercantum pada setiap pasal akad syariah dapat dilihat konstruksi hukumnya telah sesuai atau tidak sesuai dengan hukum kontrak syariah. Notaris dalam memformulasikan akta akad koperasi syariah, harus juga memperhatikan hal yang diatur didalam Undang-undang Jabatan Notaris, serta pentingnya pemahaman di bidang lembaga keuangan syariah. Peraturan khusus mengenai bentuk akta syariah atau klausul akta akad syariah belum ada sampai sejauh ini. Pada prakteknya, akad yang dibuat antara pihak BMT dan Nasabah masih mengacu pada hukum positif, begitu juga akad pembiayaaan yang dibuat secara notariil.

Bentuk akta akad syariah yang dibuat secara notariil agar dapat disebut sebagai akta otentik harus memenuhi ketentuan peraturan perundang-undangan yang berlaku, maka dari itu notaris dalam memformulasikan bentuk akta akad syariah wajib memperhatikan ketentuan Undang-undang Jabatan Notaris.

Hal tersebut yang mendorong penulis untuk mengangkat permasalahan mengenai peranan Notaris dalam membuat akta akad pembiayaan di Koperasi Syariah khususnya di BMT Syariah Wanita Islam.Adapun alasan penulis memilih Koperasi BMT Syariah Wanita Islam sebagai tempat penelitian adalah karena Koperasi BMT tersebut memiliki jumlah Anggota pembiayaan yang banyak dan sebagian besar menggunakan fasilitas pembiayaan murabahah. Permasalahan hukum yang perlu dikaji dalam penelitian ini adalah : 1) bagaimanakah akad pembiayaan murabahah pada koperasi BMT? 2) bagaimana peranan Notaris dalam membuat akta akad pembiayaan murabahah di Koperasi BMT Syariah Wanita Islam? mengingat Koperasi BMT memiliki karakteristik yang berbeda dengan lembaga keuangan konvensional.

Untuk mengetahui orisinalitas pada penelitian ini, maka perlu adanya upaya komparisi atau perbandingan dengan penelitian-penelitian yang telah dilakukan sebelumnya yang memiliki kemiripian, apakah terdapat unsur-unsur perbedaan ataupun persamaan dengan kajian dalam penelitian ini. Berikut ini jurnal penelitian terdahulu yang memiliki kemiripan.

Artikel ini memiliki perbedaan dari artikel-artikel sebelumnya, seperti halnya yang ditulis oleh Sentiya Dwi Ningsih dan Munsharif Abdul Chalim yang membahas mengenai Peran Notaris 
Dalam Pelaksanaan Pembuatan Akta Akad Pembiayaan Di Bank Syariah Menurut Undangundang Nomor 2 Tahun 2014 Tentang Jabatan Notaris, dalam artikel ini membahas permasalahan mengenai peran Notaris dalam pembuatan akta akad pembiayaan di Bank Syariah (Ningsih, Sentiya Dwi \& Chalim, 2017). Selanjutnya artikel dari Muhammad Zaky Mushaffa dan Lathifa Hanim dengan judul Peranan Notaris Dalam Pengikatan Agunan Dengan Hak Tanggungan (Studi Kasus Pada KSPPS BMT Bahtera Kota Pekalongan) (Mushaffa, Muhammad Zaky \& Hanim, 2017). Artikel tersebut membahas permasalahan mengenai peran Notaris dalam pengikatan dengan hak tanggungan pada tanah yang belum bersertifikat. Selain dua artikel tersebut di atas, penulis memberikan salah satu contoh artikel lain sebagai bentuk orisinalitas dalam artikel ini, yaitu artikel dari Dudi Badruzaman yang berjudul Isu Kontemporer Peran Notaris Dalam Akad Murabahah di Lembaga Keuangan Syariah dan membahas mengenai isu-isu seputar peranan Notaris dalam Akad Murabahah di perbankan syariah (Badruzaman, 2019).

\section{B. Metode Penelitian}

Metode yang digunakan dalam penulisan artikel ini adalah metode empiris. Metode empiris ini betitik tolak dari data primer atau dasar, yakni data yang diperoleh langsung dari masyarakat sebagai sumber yang pertama dengan melalui penelitian di lapangan yang dilakukan baik melalui pengamatan (observasi), wawancara, ataupun kuesioner (Jonaedi,Efendi \& Ibrahim, 2016). Spesifikasi penelitian ini bersifat deskriptif analitis, yaitu penelitian yang bertujuan untuk melukiskan (menggambarkan) suatu permasalahan di daerah tertentu atau pada saat tertentu. Jenis dan sumber data yang dipergunakan dalam penulisan artikel ini terdiri dari data primer dan data sekunder. Data primer diperoleh langsung dari sumber pertama di lapangan melalui penelitian, yaitu dari perilaku yang ada di masyarakat sedangkan data sekunder, antara lain mencakup dokumen-dokumen resmi, buku-buku, hasil-hasil penelitian yang berwujud laporan, buku harian dan seterusnya (Soekanto, Soerjono \& Mamudji, 2001). Data primer pada penelitian ini adalah hasil pengamatan langsung di Koperasi BMT Syariah Wanita Islam Purbalingga,wawancara langsung dengan karyawan dan Notaris setempat.

\section{Hasil Dan Pembahasan}

\section{Akad Pembiayaan Murabahah Pada Koperasi BMT}

Pengertian akad dari sisi etimologi berarti ikatan antara dua perkara, baik ikatan secara nyata maupun ikatan secara maknawi, dari satu segi maupun dua segi. Adapun pengertian 
akad dalam arti khusus adalah perikatan yang ditetapkan dengan ijab kabul berdasarkan ketentuan syara' (prinsip syariah) yang berdampak pada objeknya (Imaniyati, 2018). Akad menjadi sesuatu yang penting dalam setiap transaksi, termasukakad/transaksi dalam

Bisnis syariah. Agar suatu perjanjian mendapatkan kekuatanhukum, maka harus tercatat di hadapan Notaris. Karena itu, setiap bisnis termasukdi dalamnya adalah bisnis syariah selalu membutuhkan Notaris sebagai pejabat umum yang membuat akta otentik sesuai dengan tugasnya yang diatur dalamUndang-undang Republik Indonesia Nomor 30 Tahun 2004 tentang JabatanNotaris jo Undang-undang Nomor 2 Tahun 2014 tentang Perubahan Atas Undang-undang Nomor 30 Tahun 2004 tentang Jabatan Notaris (Nurwulan, 2019).

Akad ini digunakan dalam pengikatan perjanjian antara pihak koperasi syariah dengan anggotanya dalam hal penghimpunan dana maupun penyaluran dana kepada anggotanya. Salah satu produk penyaluran dana pada koperasi syariah yaitu produk pembiayaan murabahah. Murabahah secara bahasa diambil dair kata rabiha - yarbahu - ribhan warabahan yang berarti beruntung atau memberi keuntungan, sedangkan kata ribh itu berarti kelebihan yang diperoleh dari produksi atau modal (profit). Murabahah berasal dari masdhar yang berarti "keuntungan, laba, atau faedah" (Munawwir, 1997). Secara istilah, murabahah ini banyak didefinisikan oleh para fuquha, jual beli murabahah yaitu jual beli dengan harga jualnya sama dengan harga belinya ditambah keuntungan. Gambaran murabahah ini, sebagaimana dikemukakan oleh Malikiyah, adalah jual beli barang dengan harga beli beserta tambahan yang diketahui oleh penjual dan pembeli (Janwari, 2015).

Dari uraian di atas, maka dapat dipahami bahwa yang dimaksud dengan murabahah adalah jual beli barang dengan alat tukar disertai tambahan yang telah ditentukan (resale with a state profit). Dapat disimpulkan, murabahah merupakan salah satu bentuk jual beli amanah berdasarkan pada penetapan harga, yaitu bentuk pertukaran obyek jual dengan harga yang merupakan jumlah harga perolehan ditambah laba tertentu.

Dalam murabahah ini setidaknya ada dua pihak yang terlibat, yakni penjual dan pembeli. Di samping itu, dalam murabahah ini mesti ada kejelasan tentang harga awal dan harga jual yang disampaikan oleh pihak penjual kepada pihak pembeli.(Janwari, 2015) Dalam hal pembiayaan murabahah di koperasi BMT yang menjadi penjual adalah pihak koperasi dan yang menjadi pembeli adalah anggota koperasi. 


\section{Peranan Notaris Dalam Membuat Akta Akad Pembiayaan Murabahah di Koperasi BMT Syariah Wanita Islam, Mengingat Koperasi BMT Memiliki Karakteristik yang Berbeda dengan Lembaga Keuangan Konvensional.}

Notaris merupakan pejabat umum yang memiliki kewenangan membuat akta otentik dan kewenangan lainnya sebagaimana dimaksud dalam Pasal 15 ayat (2) Undang-undang Jabatan Notaris, adalah sebagai berikut (Undang-undang Tentang Jabatan Notaris, 2014).

1) Mengesahkan tanda tangan dan menetapkan kepastian tanggal surat di bawah tangan dengan mendaftar dalam buku khusus.

2) Membukukan surat-surat di bawah tangan dengan mendaftar dalam buku khusus

3) Membuat kopi asli dari surat-surat di bawah tangan berupa salinan yang memuat uraian sebagaimana ditulis dan digambarkan dalam surat yang bersangkutan.

4) Melakukan pengesahan kecocokan fotokopi dengan surat aslinya.

5) Memberikan penyuluhan hukum dalam pembuatan akta.

6) Membuat akta yang berkaitan dengan pertanahan, atau

7) Membuat risalah lelang.

Selain wewenang Notaris diatas, ada 4 wewenang lain yang dikemukakan oleh G.H.S Lumban Tobing yaitu : (Tobing, 1983)

1. Notaris harus berwenang sepanjang yang menyangkut akta yang harus dibuat itu;

2. Notaris harus berwenang sepanjang mengenai orang untuk kepentingan siapa akta itu dibuat;

3. Notaris harus berwenang sepanjang mengenai tempat, dimana akta itu dibuat;

4. Notaris harus berwenang sepanjang mengenai waktu pembuatan akta itu.

Melihat kewenangan dan peranan Notaris yang sangat penting tersebut di atas maka Notaris harus memiliki pengetahuan atau wawasan yang luas, salah satunya mengenai teknik pembuatan akta yang akan dibuat nantinya, karenanya apabila Notaris itu melakukan pelanggaran terhadap ketentuan tertentu yang diakibatkan oleh minimnya pengetahuan atau wawasannya maka akan berakibat pada akta yang dibuatnya tersebut hanya mempunyai kekuatan pembuktian di bawah tangan, atau dapat pula akta itu menjadi batal demi hukum, sehingga bagi pihak yang menderita kerugian dapat menuntut penggantian biaya, ganti rugi dan bunga kepada Notaris seperti yang tertera pada Pasal 84 Undang-undang Nomor 30 Tahun 2004 Tentang Jabatan Notaris (Undang-undang Tentang Jabatan Notaris, 2014). 
Akta Notaris merupakan perjanjian para pihak yang mengikat mereka yang membuatnya, oleh karena itu syarat-syarat sahnya suatu perjanjian harus dipenuhi seperti yang tertera pada pasal 1320 KUHPerdata. Pada pasal tersebut terdapat dua syarat yaitu syarat subyektif dan syarat obyektif. Syarat subyektif yaitu syarat yang berkaitan dengan subjek yang membuat atau mengadakan perjanjian, yang terdiri dari kata sepakat dan cakap bertindak untuk melakukan suatu perbuatan hukum. Sedangkan syarat objektif yaitu syarat yang berkaitan dengan perjanjian itu sendiri atau berkaitan dengan objek yang dijadikan perbuatan hukum oleh para pihak, yang terdiri dari suatu hal tertentu dan sebab yang tidak dilarang (Kitab Undang-undang Hukum Perdata, n.d.).

Keberadaan akta notaris digunakan untuk melindungi dan menjamin hak dan kewajiban para pihak yang mengadakan perjanjian sehingga apabila di kemudian hari ada salah satu pihak yang melanggarnya maka dapat dikenakan sanksi atau hukuman. Hal inilah yang membuat masyarakat percaya, bahwa Notaris dapat menuangkan kehendak mereka dalam bentuk akta notariil serta memberikan perlindungan hukum.

Akta otentik sebagaimana halnya juga dengan akta notaris, pada dasarnya memiliki tiga kekuatan pembuktian, yaitu kekuatan pembuktian lahiriah, kekuatan pembuktian formil dan kekuatan pembuktian materiil.(Pramono, 2015)

\section{a. Kekuatan Pembuktian Lahiriah}

Kekuatan pembuktian lahiriah, artinya adalah kemampuan dari akta itu sendiri untuk membuktikan dirinya sebagai akta otentik. Menurut Pasal 1875 KUHPerdatakekuatan pembuktian lahiriah itu tidak ada pada akta dibawah tangan. Akta dibawah tangan hanya berlaku sah terhadap siapa akta itu dipergunakan, apabila pihak yang disebutkan dalam akta mengakui kebenaran tanda tangan miliknya (Kitab Undang-undang Hukum Perdata, n.d.).

Akta otentik membuktikan sendiri keabsahannya. Hal itu mengandung arti bahwa suatu akta yang memenuhi syarat dan memiliki bentuk seperti akta otentik, maka akta tersebut berlaku dan dianggap seperti aslinya (acta publika probant seseipsa) sampai ada pembuktian sebaliknya. Dengan kekuatan pembuktian lahiriah akta otentik, maka persoalan pembuktiannya hanyalah mengenai keaslian tanda tangan pejabat dalam akta. Menurut Pasal 148 KUHPerdata, pembuktian sebaliknya oleh pihak lawan hanya diperkenankan dengan memakai surat, saksisaksi dan ahli (Kitab Undang-undang Hukum Perdata, n.d.). 
Kekuatan pembuktian lahiriah suatu akta otentik merupakan pembuktian yang lengkap, berlaku terhadap setiap orang dan tidak terbatas kepada para pihak saja. Sebagai alat bukti. Keistimewaan akta otentik (akta pejabat maupun akta para pihak) terletak pada kekuatan pembuktian lahiriahnya. Akta notaris bentuk lahiriah yang sempurna, berlaku dan mengikat terhadap setiap orang sebagai suatu akta otentik, oleh karena ia dibuat dan ditanda tangani oleh pejabat negara yang berwenang untuk itu.

\section{b. Kekuatan Pembuktian Formal}

Akta otentik yang memiliki kekuatan pembuktian formal berarti terjaminnya kebenaran dan kepastian tanggal akta, kebenaran tanda tangan yang terdapat dalam akta, indentitas dari orang-orang yang hadir (comparaten) dan juga tempat dimana akta itu dibuat.

Dengan tidak mengurangi pembuktian sebaliknya, maka pembuktian formal akta otentik merupakan pembuktian lengkap, dimana kekuatan pembuktian akta pejabat maupun akta para pihak adalah sama, artinya adalah bahwa keterangan pejabat yang terdapat dalam kedua golongan akta maupun keterangan para pihak dalam akta tersebut memiliki kekuatan pembuktian formal dan berlaku terhadap setiap orang.

\section{c. Kekuatan Pembuktian Material}

Kekuatan pembuktian material akta otentik merupakan suatu kepastian bahwa para pihak tidak hanya sekedar menghadap dan Kekuatan Pembuktian Akta yang Dibuat oleh Notaris Selaku Pejabat Umum Menurut Hukum Acara Perdata di Indonesia menerangkan kepada notaris akan tetapi juga membuktikan bahwa mereka juga telah melakukan seperti apa yang tercantum dalam materi akta.

Kekuatan pembuktian akta notaris menurut Pasal 1870, 1871 dan 1875 KUHPerdata memberikan pembuktian yang sempurna dan mengikat tentang kebenaran yang terdapat dalam akta bagi para pihak yang bersangkutan, ahli waris serta penerima hak, dengan pengecualian bilamana yang tercantum dalam akta hanya sekedar penuturan belaka atau tidak memiliki hubungan langsung dengan akta (Kitab Undang-undang Hukum Perdata, n.d.).

Notaris membuat akta karena ada permintaan dari para pihak yang menghadap, tanpa ada permintaan dari para pihak, Notaris tidak akan membuat akta apapun, dan Notaris membuat akta yang dimaksud berdasarkan alat bukti atau keterangan atau pernyataan 
penghadap/para pihak yang dinyatakan atau diterangkan atau diperlihatkan kepada atau dihadapan Notaris, dan selanjutnya Notaris membingkai secara lahiriah, formil dan materil dalam bentuk akta Notaris, dengan tetap berpijak pada aturan hukum dan tata cara atau prosedur pembuatan akta dan aturan hukum yang berkaitan dengan tindakan hukum yang bersangkutan yang dituangkan dalam akta (Mushaffa, Muhammad Zaky \& Hanim, 2017).

\section{Simpulan}

Akad Pembiayaan Murabahah adalah perikatan yang sesuai dengan prinsip syariah mengenai jual beli barang dengan alat tukar disertai tambahan keuntungan yang telah ditentukan. Dalam akad murabahah ini setidaknya ada dua pihak yang terlibat, yakni penjual dan pembeli. Selain itu, dalam murabahah ini harus ada kejelasan tentang harga awal dan harga jual yang disampaikan oleh pihak penjual kepada pihak pembeli. Dalam hal ini yang menjadi penjual adalah pihak koperasi BMT dan yang menjadi pembeli adalah anggota koperasi. Peranan notaris dalam membuat akta pembiayaan murabahah sesuai dengan kewenangan notaris yang tercantum pada Pasal 1 angka 1 Undang-undang Nomor 2 tahun 2014 tentang UUJN-P yaitu membuat akad pembiayaan murabahah antara koperasi syariah dengan nasabah adalah untuk memberikan sifat otentik pada akta tersebut dalam rangka memberikan kepastian hukum bagi para pihak. Kepastian hukum yang dimaksudkan adalah akta pembiayaan murabahah yang dibuat secara otentik harus dapat menjamin adanya kepastian hukum dalam sudut pandang perjanjian, karena dalam perjanjian/akad pembiayaan murabahah menimbulkan perikatan yang berlaku sebagai Undangundang bagi para pihak yang membuatnya. Akta pembiayaan murabahah yang dibuat secara otentik juga disebut sebagai alat pembuktian yang sempurna karena memiliki 3 kekuatan nilai pembuktian, yaitu: kekuatan pembuktian lahir, kekuatan pembuktian formil dan kekuatan pembuktian materiil.

\section{DAFTAR PUSTAKA}

\section{Buku}

Adjie, Habib \& Hafidh, M. (2011). Akta Perbankan Syariah (Yang Selaras Pasal 38 UUJN). Semarang: Pustaka Zaman.

Imaniyati, N. S. (2018). Aspek-Aspek Hukum BMT(Baitul Maal Wat Tamwil). Bandung: Citra Aditya Bakti.

Janwari, Y. (2015). Lembaga Keuangan Syariah. Bandung: Remaja Rosdakarya. 
Jonaedi, Efendi \& Ibrahim, J. (2016). Metode Penelitian Hukum Normatif dan Empiris. Jakarta: Kencana.

Munawwir, A. W. (1997). Al-Munawwir, Kamus Arab Indonesia. Surabaya: Pustaka Progresif.

Soekanto, Soerjono \& Mamudji, S. (2001). Penelitian Hukum Normatif Suatu Tinjauan Singkat. Jakarta: Raja Grafindo.

Tobing, G. H. . L. (1983). Peraturan Jabatan Notaris. Jakarta: Erlangga.

\section{Artikel Jurnal}

Badruzaman, D. (2019). Peran Notaris Dalam Pelaksanaan Pembuatan Akta Akad Pembiayaan Di Bank Syariah Menurut Undang-undang Nomor 2 Tahun 2014 Tentang Jabatan Notaris. Muslim Heritage, Vol. 4 No. 1.

Hidayat, S. (2018). Persepsi Masyarakat Terhadap Baitul Maal Wat Tamwil (BMT) Dalam Pemberdayaan Ekonomi Masyarakat. Journal of Islamic Economics, Vol. 2 No. 2, hlm. 198212.

Mushaffa, Muhammad Zaky \& Hanim, L. (2017). Peranan Notaris Dalam Pengikatan Agunan Dengan Hak Tanggungan (Studi Kasus Pada KSPPS BMT Bahtera Kota Pekalongan). Jurnal Akta, Vol. 4 No. 1, hlm. 41-46.

Ningsih, Sentiya Dwi \& Chalim, M. A. (2017). Peran Notaris Dalam Pelaksanaan Pembuatan Akta Akad Pembiayaan Di Bank Syariah Menurut Undang-undang Nomor 2 Tahun 2014 Tentang Jabatan Notaris. Jurnal Akta, Vol. 4 No. 1, hlm. 79-82.

Nurwulan, P. (2019). Akad Perbankan Syariah dan Penerapannya dalam Akta Notaris Menurut Undang-undang Jabatan Notaris. Hukum, Vol. 25 No. 3, hlm. 623-644.

Pramono, D. (2015). Kekuatan Pembuktian Akta yang Dibuat Oleh Notaris Selaku Pejabat Umum Menurut Hukum Acara Perdata Di Indonesia. Lex Jurnalica, Vol. 12 No. 3, hlm. 248-258.

Prastiawati, Fitriani \& Darma, E. S. (2016). Peran Pembiayaan Baitul Maal Wat Tamwil Terhadap Perkembangan Usaha dan Peningkatan Kesejahteraan Anggotanya dari Sektor Mikro Pedagang Pasar Tradisional. Akutansi Dan Investasi, Vol 17 No. 2, hlm. 197-208.

Rusby, Z. \& H. Z. \& H. (2016). Analisa Permasalahan Baitul Maal Wat Tamwil (BMT) melalui Pendekatan Analytical Network Process (ANP). Al-Hikmah, Vol 13 No. 1, hlm. 1412-5382.

\section{Undang-undang dan Peraturan}

Undang-undang Tentang Jabatan Notaris. , (2014).

Undang-undang Tentang Perkoperasian. (1992). 
Kitab Undang-undang Hukum Perdata.

Peraturan Pemerintah Tentang Pelaksanaan Kegiatan Usaha dan Simpan Pinjam dan Pembiayaan Syariah Oleh Koperasi. (2017). 